\title{
Minimizing System Modification in an Incremental Design Approach
}

Pop, Paul; Eles, Petru; Pop, Traian; Peng, Zebo

Published in:

Ninth International Symposium on Hardware/Software Codesign. CODES 2001 (IEEE Cat. No.01TH8571)

Link to article, DOI:

10.1109/HSC.2001.924672

Publication date:

2001

Document Version

Publisher's PDF, also known as Version of record

Link back to DTU Orbit

Citation (APA):

Pop, P., Eles, P., Pop, T., \& Peng, Z. (2001). Minimizing System Modification in an Incremental Design Approach. In Ninth International Symposium on Hardware/Software Codesign. CODES 2001 (IEEE Cat. No.01TH8571) (pp. 183-188). https://doi.org/10.1109/HSC.2001.924672

\section{General rights}

Copyright and moral rights for the publications made accessible in the public portal are retained by the authors and/or other copyright owners and it is a condition of accessing publications that users recognise and abide by the legal requirements associated with these rights.

- Users may download and print one copy of any publication from the public portal for the purpose of private study or research.

- You may not further distribute the material or use it for any profit-making activity or commercial gain

- You may freely distribute the URL identifying the publication in the public portal 


\title{
Minimizing System Modification in an Incremental Design Approach
}

\author{
Paul Pop, Petru Eles, Traian Pop, Zebo Peng
}

Department of Computer and Information Science, Linköpings universitet, Sweden

\section{Incremental Design}

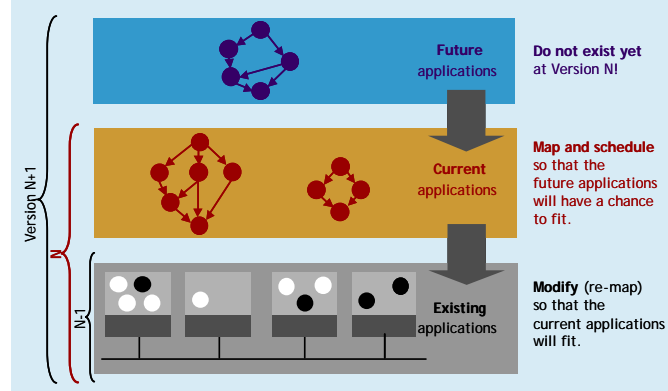

- Start from an already existing system with applications

- Implement new functionality on this system Mapping and Scheduling

- To reduce design and testing time:

As few as possible modifications of the existing applications

- After the new functionality has been implemented: It should be easy to add functionality in the future

\section{Design Criteria}

a)

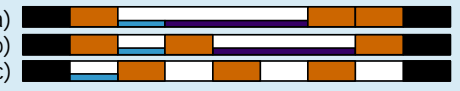

\section{Existin Curren $\square$ Slac}

Fuflure $\mathrm{P}_{1} \rightleftharpoons \mathrm{t}_{2}$

- First criterion: $\mathrm{C}_{1}{ }^{\mathrm{P}}, \mathrm{C}_{1}{ }^{\mathrm{m}}$

How well the resulted slack sizes

accommodate a future application

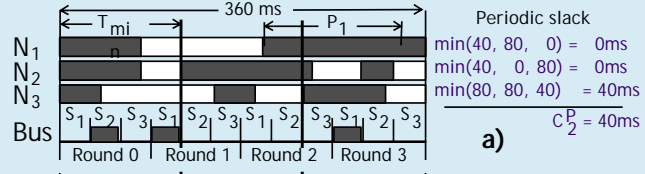

$\mathrm{N}_{1} \leftarrow$ Period $0 \rightarrow$ - Period $1 \rightarrow$ - Period $2 \rightarrow \min (40,40,40)=40 \mathrm{~ms}$

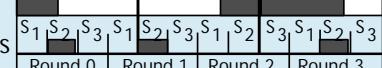
$\min (40,40,40)=40 \mathrm{~ms}$ $\min (80,80,40)=40 \mathrm{~ms}$ \begin{tabular}{l|l|l|l|l|l|}
\hline Round 0 & Round 1 & Round 2 & Round 3
\end{tabular}

b)

- Second criterion: $\mathrm{C}_{2}{ }^{\mathrm{P}}, \mathrm{C}_{2}{ }^{\mathrm{m}}$ 0

accommodate $\mathbf{T}_{\text {min }}, \mathbf{t}_{\text {need }}$ and $\mathbf{b}_{\text {need }}$

Paul Pop, Petru Eles, Traian Pop, Zebo Peng:

An approach to Incremental Design of Distributed Embedded Systems,

Design Automation Conference, 2001

\section{Summary}

Mapping and scheduling of distributed

embedded systems for hard-real time applications

- Static cyclic scheduling of processes and messages,

- Bus access scheme: time-division multiple-access.

- Incremental design process

- Already existing system,

- Implement new functionality,

- a) Existing system modified as little as possible b) new functionality can be easily added to the system.

- Mapping strategy

- a) Subset selection to minimize modification time,

- b) Two design criteria, objective function.

\section{Problem Formulation}

- Input

- A set of existing applications.

- A current application to be mapped.

- The system architecture.

- Output

- A mapping and scheduling of the current application, so that the incremental design requirements are satisfied.

- Requirements

- a) constraints of the current application are satisfied and minimal modifications are performed to the existing applications.

- b) new future applications can be mapped on the resulted system.

\section{Mapping Strategy}

- Initial mapping and scheduling

- Requirement a)

Subset selection problem

Select that subset $\Omega$ of existing applications so that the current application fits and the modification cost $R(\Omega)$ is minimized:

$R(\Omega)=\sum_{\Gamma_{i} \in \Omega} R_{i}$

Three approaches to the subset selection problem

- Exhaustive Search (ES)

- Ad-Hoc Solution (AH)

- Subset Selection Heuristic (SH)

- Requirement b)

Objective function minimization:

$C=w_{1}^{P}\left(C_{1}^{P}\right)+w_{1}^{m}\left(C_{1}^{m}\right)+w_{2}^{P} \max \left(0, t_{\text {need }}-C_{2}^{P}\right)+w_{2}^{m} \max \left(0, b_{\text {need }}-C_{2}^{m}\right)$
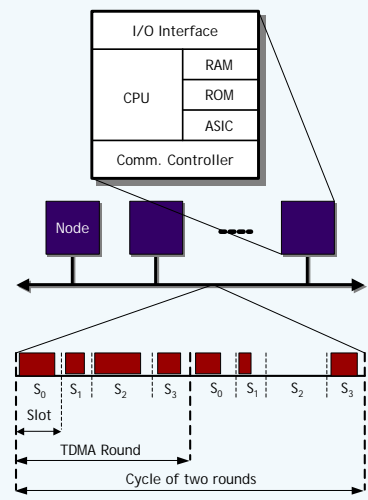

Characterizing existing applications

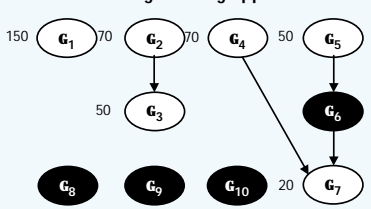

Characterizing future applications: - Typical WCETs

- Typical message sizes

Smallest expected period $\mathbf{T}_{\mathrm{m}}$

- Expected necessary processor time $\mathbf{t}_{\text {nee }}$ - Expected necessary bandwidth $\mathbf{b}_{\text {need }}$
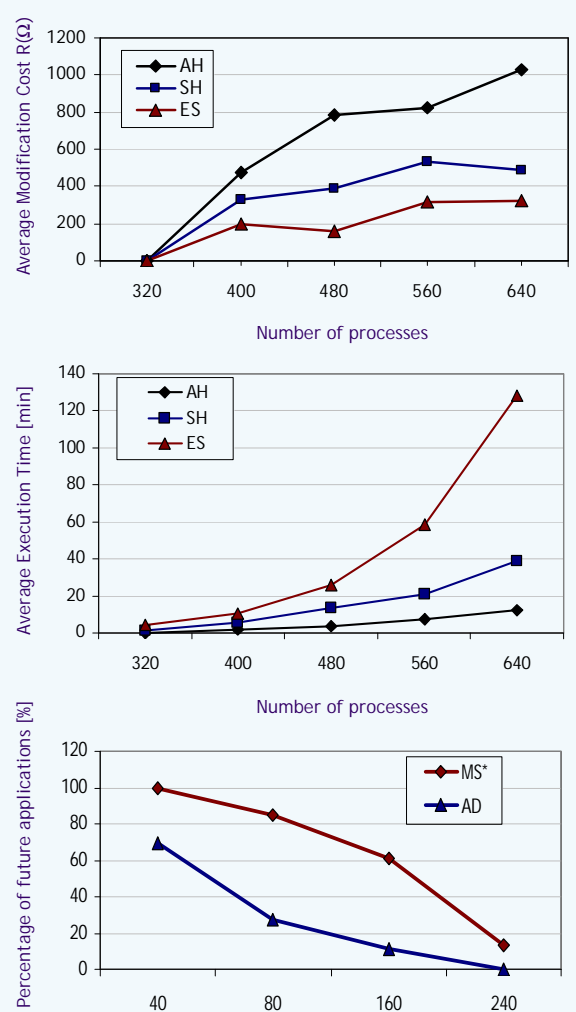

Number of processes in the current application 